\author{
А.А. Леках, О.М. Гурін, В.В. Старцев, В.В. Просяник
}

Харківський начіональний університет Повітряних Сил ім. І. Кожедуба, Харків

\title{
АНАЛІЗ ФАКТОРІВ, ЯКІ ВПЛИВАЮТЬ НА ОРГАНІЗАЦІЮ ДОСТАВКИ ВІЙСЬКОВИХ ВАНТАЖІВ ДЛЯ ПОТРЕБ ПОВІТРЯНИХ СИЛ ЗБРОЙНИХ СИЛ УКРАЇНИ
}

В статті розглянути основні фактори, які впливають на організачію та здійснення доставки озброєння та військової техніки і матеріально-технічних засобів в системі логістичного забезпечення Повітряних Сил Збройних Украӥни. Визначені основні класи постачання матеріально-технічних засобів, місия їх утримання і доставки; існуюча транспортна мережа і засоби їх доставки; стратегії поповнення та технологічність процесу доставки матеріально-технічних засобів до споживачів. На підставі проведеного аналізу вироблена стратегія поповнення запасів озброєння та військової техніки і матеріально-технічних засобів, яка у відповідності від конкретної оперативно-логістичної обстановки, шзо склалася, поділяється на безперервну, періодичн, періодичне поповнення з екстреними доставками та стратегію поповнення запасів матеріально-технічних засобів за рівнем.

Ключові слова: система логістичного забезпечення, військовий вантаж, поповнення запасів, перевезення, технологічність доставки, транспортна мережа.

\section{Вступ}

Постановка проблеми. Сучасні погляди на форми і способи ведення воєнних дій, триваючий процес реформування Повітряних Сил Збройних Сил України (далі - ПС ЗС України), та видів забезпечення їх бойових дій вимагають по-новому розглянути роль і місце системи логістичного забезпечення ПС ЗС України у сучасних умовах ведення збройної боротьби, особливо в питаннях своєчасного реагування на швидко мінливий стан бойової обстановки.

Високу ефективність застосування військових частин (підрозділів) ПС ЗС України під час ведення бойових дій неможливо досягти без підтримання озброєння і військової техніки (ОВТ) в боєздатному стані та вирішення завдань життєдіяльності. Вирішення цих завдань покладається на систему логістичного забезпечення, складовою якої $\epsilon$ функція забезпечення ОВТ і матеріально-технічними засобами (Мт3) та перекидання військових вантажів під час проведення логістичних операцій з забезпечення необхідними ресурсами військових частин (підрозділів). Ця функція представляє собою сукупність матеріальних, транспортних, інформаційних та інших компонентів. Основним завданням функції забезпечення ОВТ та Мт3 є своєчасна їх доставка до споживачів. При цьому, у зв'язку зі значним просторовим рознесенням споживачів, від органів постачання (об'єднаних центрів забезпечення, арсеналів, складів) до військових частин (підрозділів) стає актуальною задача швидкого і оптимального прийняття рішення щодо організації забезпечення необхідними матеріальними ресурсами. Для цього необхід- но визначити величини оптимальних запасів ОВТ i Мт3, можливі (раціональні) маршрути їх доставки 3 урахуванням різних аварійних ситуацій, дорожніх заторів, масштабних дорожніх робіт, природних катаклізмів та інших факторів, а також оптимальні 3 них за критерієм необхідного значення часу і (або) вартості перекидання військові вантажів.

Аналіз останніх досліджень і публікацій. На теперішній час вся система матеріально-технічного (технічного, тилового, тощо) згідно відповідного керівного документу [1] реорганізована в систему логістичного забезпечення. Проте, основні завдання заново створеної системи логістичного забезпечення ПС ЗС України залишились в цілому попередніми, це: збір та узагальнення даних про наявність, стан і витрати OBT і Мт3; визначення потреб Мт3 за класами (номенклатурами) постачання, своєчасне витребування їх та забезпечення військ через служби постачання органів військового управління; створення і ешелонування запасів ОВТ і Мт3, їх зберігання, розосередження, проведення всіх видів технічного обслуговування, підготовка до транспортування, бойового застосування; поповнення витрат i втрат ОВТ і Мт3; управління силами та засобами логістики.

Аналіз літератури [2-10] свідчить, що основна увага авторів приділяється питанню удосконалення системи логістичного забезпечення ПС ЗС України.

В публікаціях визначено, що характерними рисами логістичних процесів є зростаюча актуальність більш оперативного збору, обробки та аналізу інформації про стан Мт3 на кожному етапі їх руху. Це обумовлює необхідність покращення інформаційно- 
го забезпечення доставки Мт3 та доцільність залучення цих логістичних операторів до проведення окремих операцій і робіт в процесі доставки Мт3.

На сучасному етапі реформування ЗС України зросла необхідність у розробці нових нормативних документів, які покращують якість організації доставки військових вантажів в системі логістичного забезпечення військ згідно вимогам євроатлантичного альянсу. 3 цією метою процес удосконалення науково-методичного апарату якості доставки Мт3 пропонується поділити на відповідні взаємопов'язані етапи, один із яких направлений на проведення аналізу факторів що впливають на організацію доставки Мт3, з подальшим визначенням способів і підходів до оцінювання ефективності доставки Мт3 у системі логістичного забезпечення ПС ЗС України.

Метою статті $\epsilon$ проведення аналізу факторів, що впливають на доставку матеріальних ресурсів до підрозділів і військових частин в сучасних умовах ведення військових конфліктів, який дозволить виробити стратегію поповнення запасів в системі логістичного забезпечення, з подальшим розробленням науково-методичних рекомендацій щодо організації доставки необхідних матеріальних ресурсів військовим частинам (підрозділам) ПС ЗС України як в мирний, так і в воєнний час.

\section{Виклад основного матеріалу}

Аналіз набутого досвіду ведення бойових дій під час виконання завдань у складі сил антитерористичної операції і операції Об'єднаних сил на сході України, збройного конфлікту (протистояння) на Близькому Сході та Закавказзя свідчить, що сучасні воєнні конфлікти характеризуються наступними особливостями:

- швидко мінливим станом бойової обстановки;

- високою імовірністю раптового нападу противника з різних напрямків;

- використанням сучасних зразків озброєння, в тому числі високоточної зброї, новітніх боєприпасів, авіаційних засобів ураження та ударних безпілотних літальних апаратів.

Ці особливості в цілому можуть суттєво впливати на ефективність системи логістичного забезпечення ПС ЗС України. В цих умовах набуває значної ваги питання організації і здійснення швидкої, чіткої i безперебійної доставки Мт3 військам, як в мирний час, так і при веденні бойових дій в сучасних умовах збройної боротьби.

Процес організації і здійснення доставки Мт3 в системі логістичного забезпечення ПС ЗС України відбувається в певних умовах оперативно-логістичної обстановки, під впливом різних факторів: зовнішніх і внутрішніх, негативних і позитивних, характер яких може бути ймовірним або детермінованим (конкретним, ясним і чітким).

До основних факторів, які впливають на організацію і здійснення доставки ОВТ та Мт3 в системі логістичного забезпечення ПС ЗС України відносять:

- види Мт3 за класами постачання, місця їх утримання;

- транспортна мережа і засоби доставки ОВТ і Мт3;

- стратегія поповнення запасів ОВТ і Мт3;

- технологічність процесу доставки ОВТ і Мт3.

Постачання ОВТ та Мт3 як складова логістичного забезпечення охоплює закупівлю, складування, доставку (транспортування), їх оприбуткування, внутрішню перевірку та зберігання. Функція постачання охоплює усі Мт3, що використовуються для підтримання військових частин (підрозділів) ПС ЗС України у готовності до виконання завдань за призначенням та підтримання ОВТ у боєздатному стані як в мирний, так і в воєнний час.

Постачання Мт3 здійснюється відповідно до п’яти класів постачання [1]:

клас I - продовольство (продукти харчування та корм), що споживаються особовим складом та тваринами, для якого встановлені єдині норми;

клас II - предмети постачання, що видаються за нормами, установленими штатами та табелями до них (озброєння та зброя, військова техніка та технічні засоби, обмундирування та спорядження, інструменти, запасні частини тощо);

клас III - усі види нафтопродуктів та пальномастильних матеріалів, паливо;

клас IV - предмети постачання, норми видачі яких не визначені встановленими штатами та табелями (фортифікаційні та будівельні матеріали);

клас $\mathrm{V}$ - різні види ракет, боєприпасів, вибухових та хімічних речовин.

Під рівнем забезпечення військових частин (підрозділів) ОВТ і Мт3 розуміється укомплектування їх відповідно до табелю до штату, а також їх постачання для накопичення в запасах по існуючих нормах. Цілями і завданнями забезпечення є своєчасне і повне укомплектування військових частин (підрозділів) ОВТ і Мт3 відповідно до їх штатнотабельної потреби. Забезпеченість на початок бойових дій повинна відповідати такому рівню, щоб військові частини (підрозділи) спроможні були вести бойові дії з періодом найбільшого бойового напруження (перші 2-3 доби бойових дій) автономно (без втручання центральних органів постачання).

Запаси Мт3 - це певна їх кількість, яка утримується на арсеналах, базах, складах, а також безпосередньо в військових частинах (підрозділах), і призначена для задоволення потреби в цих засобах військ у мирний та воєнний час.

За призначенням і належністю до певного рівня 
забезпечення (місць утримання) запаси ОВТ і Мт3 розподіляються на: стратегічні, оперативні та військові, а за цільовим призначенням та порядком витрат розподіляються на: витратні, непорушні, незнижувані та додаткові.

Ешелонування Мт3 здійснюється за відповідними, визначеними керівними документами норм забезпечення - кількістю Мт3 для підрозділів і військових частин, яка призначена для використання в певний період часу. Розміщення запасів Мт3 (ешелонування), умови зберігання, режими їх утримання та технологія підготовки повинні забезпечувати:

- високий ступінь бойової готовності військових частин;

- раціональне розосередження запасів Мт3 3 метою підвищення живучості;

- малі витрати на зберігання та обслуговування Мт3;

- більші терміни експлуатації Мт3.

Транспортна мережа України в цілому є розвинутим сучасним промислово-господарським комплексом і включає усі види шляхів сполучення. Які в залежності від терміну служби поділяються на постійні і тимчасові, від належності (форми власності) - на шляхи загального користування, відомчі (технологічні) шляхи та приватні, від народногосподарського і адміністративного значення - на шляхи державного значення, міжнародні, національні шляхи, регіональні шляхи та територіальні шляхи, від розрахункової інтенсивності руху за (на) добу - на шляхи відповідні категорії (від першої до п’ятої) [11].

Але існуючий стан дорожньо-транспортної інфраструктури прогнозованого району бойових дій військових частин (підрозділів) ПС ЗС України у будь-якій частині України неспроможний в повній мірі забезпечити безперебійну доставку ОВТ та інших Мт3. Для надійного забезпечення військ необхідними матеріальними ресурсами, скоєння маневру та пересування військ необхідно створювати на деяких ділянках місцевості додаткові елементи транспортних комунікацій.

Враховуючи досвід сучасних збройних конфліктів, проведення антитерористичної операції і операції об'єднаних сил на сході України, можливості порушення дорожньої інфраструктури і комунікацій у районах бойового призначення під час ведення бойових дій потребуються наступні заходи:

- завчасну доставку Мт3 у райони бойового призначення (ведення бойових дій) частин (підрозділів) ПС ЗС України;

- створення підвищених запасів Мт3 у підрозділах, що діють у відриві від основних сил;

- надійний захист колон рухомих засобів, що доставляють Мт3;

- визначення доцільного складу та довжини колон для перевезення Мт3, що дозволить здійснювати їх безперервний надійний захист супроводжуючими підрозділами охорони;

- вибір шляхів доставки Мт3;

- у разі ускладнення обстановки для доставки ресурсів залучення всіх видів транспорту (автомобільного, залізничного, повітряного та водного);

- більш тісної взаємодії з центральними та місцевими органами виконавчої влади, іншими державними органами 3 питань доставки Мт3 військовим частинам (підрозділам).

Під стратегією поповнення запасів Мт3 розуміють правило поповнення запасу Мт3 по мірі його витрачання. До стратегій поповнення запасів Мт3 відносяться безперервна, періодична, періодичне поповнення з екстреними доставками та стратегія поповнення за рівнем [12, 13].

Стратегія безперервного поповнення призначена для усунення необхідності в замовленнях на поповнення запасів Мт3. Метою даної стратегії є встановлення ефективного логістичного плану, спрямованого на безперервне поповнення запасів Мт3 у військових частинах (підрозділах) виключаючи проміжні ланки постачання.

При стратегії періодичного поповнення запас Мт3 даного типу періодично, через фіксовані, заздалегідь задані інтервали часу (періоди поповнення) поповнюється до початкового рівня. Передбачається, що періодичне поповнення будь-якого запасу Мт3 проводиться тільки 3 невичерпного джерела поповнення. Періодичне поповнення застосовується для відновлення запасів Мт3, наприклад запасних частин (ЗЧ) у всіх видах комплектів запасних частин, інструменту та приладів (ЗІП) (одиноких, групових, ремонтних тощо). Стратегія періодичного поповнення характеризується одним числовим параметром - періодом поповнення даного запасу ЗЧ.

При стратегії періодичного поповнення з екстреними доставками, крім планового поповнення, у випадках, коли зразок ОВТ простоює через відсутність необхідної ЗЧ, здійснюється позапланове поповнення запасу ЗЧ до початкового рівня. Стратегія періодичного поповнення з екстреними доставками застосовується для відновлення запасів у всіх видах комплектів ЗІП. Така стратегія характеризується двома числовими параметрами, а саме періодом поповнення запасу ЗЧ даного типу (передбачається, що планове поповнення проводиться завжди за рахунок невичерпного джерела поповнення) і середньою тривалістю екстреної доставки ЗЧ даного типу із групового ЗІП або з невичерпного джерела поповнення.

У практиці експлуатації ОВТ широкого поширення набула така стратегія поповнення запасів зразків ОВТ, як періодична стратегія поповнення.

Поповнення запасів зразків ОВТ відбувається у випадках, коли зразок ОВТ досягнув граничного 
терміну служби, підлягає зняттю 3 експлуатації 3 подальшим проведенням певного ряду робіт, або під час експлуатації при одержанні бойових пошкоджень, або повного руйнування в результаті бойових дій.

Поповнення запасів засобів ураження (далі 3У) (авіаційних засобів ураження, зенітних керованих ракет, ракет і боєприпасів), пально-мастильних матеріалів (ППМ) та продовольства здійснюється за рахунок запасів, які утримується для задоволення потреби в цих засобах військ у мирний та воєнний час. Запаси ЗУ, ПММ та продовольства за цільовим призначенням та порядком витрат розподіляються на: витратні, непорушні, незнижувані та додаткові.

Наприклад, при поповненні запасів ЗУ використовується періодична стратегія поповнення - в мирний час, безперервна стратегія поповнення за рівнем - під час ведення бойових дій.

При використанні безперервної стратегії поповнення за рівнем запасу ЗУ даного типу фіксується початковий рівень запасу $k$. Коли запас ЗУ даного типу вичерпується до рівня $k$, починається доставка ЗУ даного типу споживачу.

Стратегія безперервного поповнення за рівнем характеризується двома числовими параметрами: $k-$ рівнем поповнення запасу ЗУ даного типу (в якості параметра $k$ може використовуватись незнижуваний запас ЗУ даного типу) і $T_{\partial}$ - середньою тривалістю доставки на поповнення, тобто середнім часом доставки ЗУ даного типу з джерела поповнення. Джерелом поповнення в цьому випадку може бути арсенал, база, склад.
Технологічність процесу доставки матеріальних ресурсів передбачає якісне проведення цілого ряду робіт з підготовки до транспортування, в процесі транспортування та здачі Мт3 споживачу (військовим частинам (підрозділам)).

Єдиний технологічний процес транспортування військових вантажів - це комплексна технологія, в межах якої здійснюється чітка взаємодія всіх елементів системи логістичного забезпечення на всіх етапах доставки Мт3 до споживачів в визначений термін 3 якнайменшими витратами ресурсів та на основі інтеграції виробництва, транспорту і споживання.

Технологічні процеси, що реалізуються в логістичних ланцюгах при доставці ВВ споживачам, мають свої особливості. Вони залежать від:

- транспортних характеристик вантажу (фізико-механічні та фізико-хімічні властивості; об'єм і маса, вид тари і упаковки тощо);

- кількості вантажу (масові вантажі, вантажі в пакетах, контейнерах, на піддонах і т. ін.);

- виду транспорту та його здатності до перевезень.

Перевезення вантажів характеризуються специфічними особливостями в технології, організації та управлінні. Однак вони мають загальну технологічну основу у вигляді конкретних технологічних ланок: підготовки вантажу до перевезення; завантаження; транспортування; розвантаження; складування; подачі рухомого складу (транспорту).

Узагальнена технологічна схема доставки Мт3 до споживачів представлена на рис. 1.

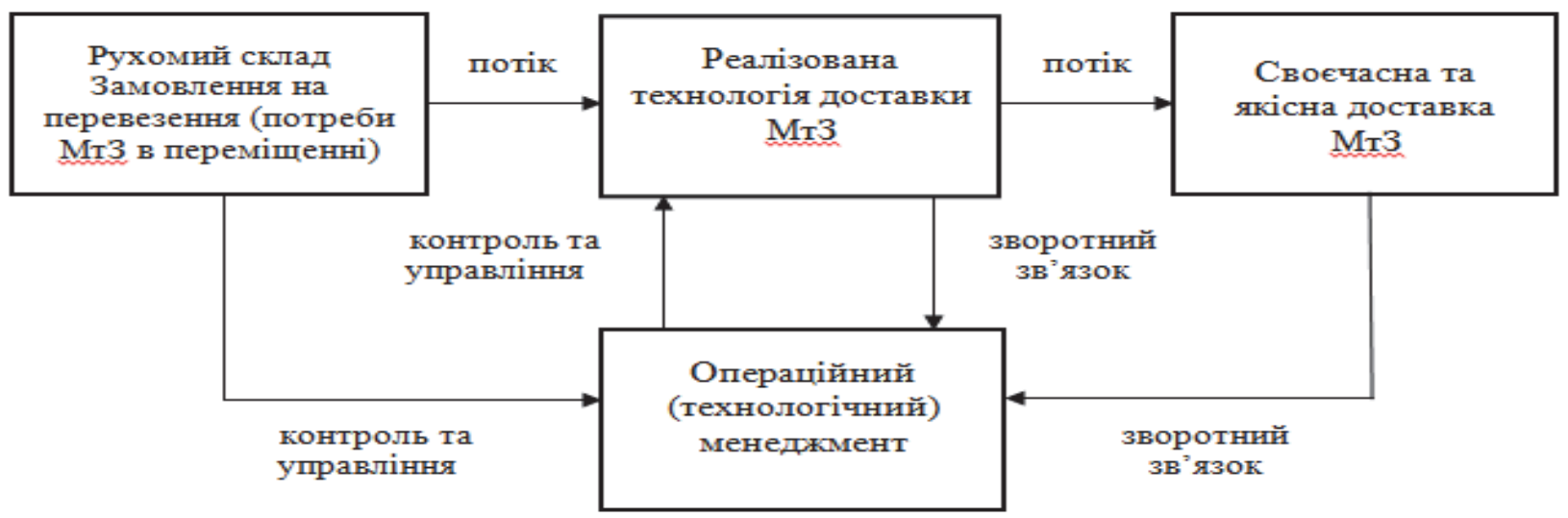

Рис. 1. Технологічна схема доставки Мт3 до споживачів Джерело: розроблено авторами.

\section{Висновки}

Таким чином, проведений в статті аналіз показав, що в сучасних умовах збройної боротьби на організацією і здійснення доставки ОВТ та Мт3 в системі логістичного забезпечення ПС ЗС України значною мірою впливає низка факторів: зовнішніх i внутрішніх, негативних і позитивних, характер яких може бути ймовірним або детермінованим. До основних факторів відносяться:

- види Мт3 за класами постачання та місця їх утримання;

- транспортна мережа та засоби доставки ОВТ і Мт3;

- стратегія поповнення запасів ОВТ і Мт3; 
- технологічність процесу доставки ОВТ і Мт3.

Наведені фактори дозволяють, при веденні бойових дій у відповідності від конкретної оператив- но-логістичної обстановки, визначити стратегію поповнення запасів потрібних для військ матеріальних ресурсів та технологічність процесу їх доставки.

\section{Список літератури}

1. Наказ Міністра оборони України від 11.10.2016 № 522 Основні положення логістичного забезпечення Збройних Сил України. - К., 2016. - 25 с.

2. Гурін О.М. Удосконалення науково-методичного апарату обгрунтування напрямів підвищення якості доставки матеріально-технічних засобів в системі логістичного забезпечення Повітряних Сил Збройних Сил України: монографія / О.М. Гурін, В.В. Старцев. - Вінниця: European Scientific Platform, 2020. - 20 с.

3. Дудар Т.Г. Основи логістики / Т.Г. Дудар, Р.В. Волошин. - Харків: Центр учбової літератури, 2012. - 176 с.

4. Науменко М.О. Удосконалення організаційної та функціональної структури логістичного забезпечення Збройних Сил України / М.О. Науменко, Л.В. Морозова // Бізнес Інформ. - 2016. - № 3. - С. 279-284.

5. Гурін О.М. Методика формування раціональної структури системи матеріального забезпечення повітряного командування Повітряних Сил Збройних Сил України у повітряної операції / О.М. Гурін // Збірник наукових праць Харківського національного університету Повітряних Сил. - 2017. - № 2(51). - С. 35-39.

6. Показники та критерії комплексної методики оцінювання ефективності виконання завдань логістичного забезпечення військових частин Повітряних Сил Збройних Сил України у збройному конфлікті / Г.С. Залевський, А.А. Леках, О.М. Гурін, В.В. Старцев, В.В. Калачова // Збірник наукових праць Харківського національного університету Повітряних Сил. - 2019. - № 3(61). - С. 45-52. https://doi.org/10.30748/zhups.2019.61.07.

7. Гурін О.М. Проведення аналізу шляхив формування обгрунтрваного раціонального варианту тилового забезпечення бойових дій ПС ЗС України / О.М. Гурін // Збірник наукових праць Харківського національного університету Повітряних Сил. - 2016. - № 1(46). - С. 37-40.

8. Дробаха Г.А. Обгрунтування показників та критеріїв ефективності системи матеріального забезпечення повітряного командування під час підготовки бойових дій / Г.А. Дробаха, О.М. Гурін // Честь і закон. - 2018. - № 1(64). - C. 78-83.

9. Кивлюк В.С. Вироблення єдиних поглядів щодо створення сучасної державної системи логістики ЗС України / В.С. Кивлюк, М.Я. Клонцак // Збірник наукових праць Військового інституту Київського національного університету ім. Т. Шевченка. - 2016. - № 51. - С. 100-110.

10. Creating a database of existing weapon system / V.V. Voinov, H.M. Kachurovskyi, A.F. Shevchenko, O.M. Hurin // Збірник наукових праць Харківського національного університету Повітряних Сил. - 2018. - № 3(57). - С. 38-42. https://doi.org/10.30748/zhups.2018.57.06.

11. Державні будівельні норми України: ДБН В.2.3.- 4: 2015. - С. 3-19.

12. Стерлигова А.Н. Управление запасами в цепи поставок / А.Н. Стерлигова. - М.: ИНФРА-М, 2008. - 430 с.

13. Шрайбфедер Дж. Эффективное управление запасами / Джон Шрайбфедер; Пер. 3 англ. - М.: Альпина Бизнес Букс, 2006. -304 с.

14. Соловйова О.О. Загальний курс транспорту / О.О. Соловйова, І.І. Висоцька, І.М. Герасимеко. - К.: НАУ, 2019. $244 \mathrm{c}$.

15. Транспортное обеспечение вооружённых сил развитых капиталистических государств // Зарубежное военное обозрение. - 1991. - С. 22-27.

16. Щелкунов В.И. Стратегии материального обеспечения Вооруженных Сил Украины в современных условиях / В.И. Щелкунов, Б.А. Пружников. - К. Наукова думка. 2001. - 280 с.

17. Бабенков В.И. Перспективные исследования военно-экономической эффективности материально-технического обеспечения войск / В.И. Бабенков, Д.С. Башкиров // Актуальные проблемы развития современной науки и образования: сборник международной научно-практической конференции. - 2017. - С. 112-113.

18. Наказ Генерального штабу Збройних Сил України від 20.06.2020. Доктрина з організації переміщень та перевезень (транспортувань) у Збройних Силах України. - К., 2020. - 30 с.

19. Всебічне забезпечення, Army Doctrine Publication (ADP 4-0 Sustainment). - 2019. - 84 c.

20. Об'єднана доктрина перевезень та транспортування НАТО, редакція В версія 1, AJP-4.4 (ALLIED JOINT MOVEMENT AND TRANSPORTATION DOCTRINE May 2013). - 2013. - 119 c.

Надійшла до редколегії 05.11.2020

Схвалена до друку 15.12.2020

\section{Відомості про авторів:}

\section{Леках Альберт Анатольович}

кандидат технічних наук

начальник науково-дослідної лабораторії

Харківського національного університету

Повітряних Сил ім. І. Кожедуба,

Харків, Україна

https://orcid.org/0000-0003-2848-2593

\section{Information about the authors:}

\author{
Albert Lekakh \\ Candidate of Technical Sciences \\ Chief of Science and Research Laboratory \\ of Ivan Kozhedub Kharkiv National \\ Air Force University, \\ Kharkiv, Ukraine \\ https://orcid.org/0000-0003-2848-2593
}


Гурін Олександр Миколайович

кандидат військових наук

старший науковий співробітник

Харківського національного університету

Повітряних Сил ім. І. Кожедуба,

Харків, Україна

https://orcid.org/0000-0002-0951-3713

\section{Старцев Володимир Вікторович}

науковий співробітник

Харківського національного університету

Повітряних Сил ім. І. Кожедуба,

Харків, Україна

https://orcid.org/0000-0002-1562-6669

\section{Просяник В'ячеслав Володимирович}

молодший науковий співробітник

Харківського національного університету

Повітряних Сил ім. І. Кожедуба,

Харків, Україна

https://orcid.org/0000-0002-6419-0830

\author{
Alexander Gurin \\ Candidate of Military Sciences \\ Senior Research Associate \\ of Ivan Kozhedub Kharkiv National \\ Air Force University, \\ Kharkiv, Ukraine \\ https://orcid.org/0000-0002-0951-3713
}

\author{
Volodymyr Startsev \\ Research Associate \\ of Ivan Kozhedub Kharkiv National \\ Air Force University, \\ Kharkiv, Ukraine \\ https://orcid.org/0000-0002-1562-6669
}

\author{
Vyacheslav Prosyanyk \\ Junior Researcher Associate \\ of Ivan Kozhedub Kharkiv \\ National Air Force University, \\ Kharkiv, Ukraine \\ https://orcid.org/0000-0002-6419-0830
}

\title{
АНАЛИЗ ФАКТОРОВ, ВЛИЯЮЩИХ НА ОРГАНИЗАЦИЮ ДОСТАВКИ ВОЕННЫХ ГРУЗОВ ДЛЯ НУЖД ВОЗДУШНЫХ СИЛ ВООРУЖЕННЫХ СИЛ УКРАИНЫ
}

\author{
А.А. Леках, А.Н. Гурин, В.В.Старцев, В.В. Просяник
}

В статье рассмотрены основные факторы, влияющие на организаџию и осуществление доставки вооружения и военной техники и материально-технических средств в системе логистического обеспечения Вооруженных Сил Украины. Определены основные классы поставки материально-технических средств, места их содержсания и доставки; существующая транспортная сеть и средства их доставки; стратегии пополнения и технологичность процесса доставки материально-технических средств к потребителям. На основании проведенного анализа выработана стратегия пополнения запасов вооружения, военной техники и материально-технических средств, которая в соответствии от сложсивщейся конкретной оперативно-логистической обстановки делится на непрерывную, периодическую, периодическое пополнение с экстренными поставками и стратегию пополнения запасов материально-технических средств по уровню.

Ключевые слова: система логистического обеспечения, военный груз, пополнение запасов, перевозки, технологичность доставки, транспортная сеть.

\section{ANALYSIS OF FACTORS AFFECTING THE ORGANIZATION OF DELIVERY OF MILITARY CARGO FOR THE NEEDS OF THE AIR FORCE OF THE ARMED FORCES OF UKRAINE}

\section{A. Lekakh, A. Gurin, V. Startsev, V. Prosyanyk}

It is determined in the article that modern military conflicts are characterized by a rapidly changing combat situation, a high probability of a surprise attack by the enemy from different directions, the use of modern weapons, including precision weapons, the latest ammunition, aircraft weapons and attack unmanned aerial vehicles. These features in general can significantly affect the effectiveness of the system of logistics support for troops. In these conditions, the issue of organizing and implementing a fast, clear and uninterrupted delivery of military cargo, both in peacetime and in the conduct of hostilities in modern conditions of armed struggle, acquires significant weight. The process of organizing and carrying out the delivery of military cargo in the system of logistic support of troops occurs under certain conditions of the operational and logistic situation, under the influence of various factors: external and internal, negative and positive, the nature of which may be probable or deterministic. The main factors that affect the organization and implementation of the delivery of military cargo in the system of logistic support of troops include types of materiel by support classes, places of their containment; transport network and delivery vehicles; replenishment strategy; manufacturability of the process of delivery of material resources. Taking into account the experience of the armed conflict in the east of Ukraine and the possibility of damage to the road infrastructure and communications, during the conduct of hostilities, additional measures are taken to organize the logistics of the troops. These include the advance delivery and creation of increased stocks of materiel in areas of hostilities, the implementation of reliable protection of military cargo supply convoys, and the selection of reliable routes for their delivery. Based on the analysis carried out, a strategy was developed for replenishing stocks of weapons and military equipment and materiel, which, in accordance with the specific operational and logistic situation, is divided into continuous, periodic, periodic replenishment with emergency deliveries and a strategy for replenishing stocks of materiel and technical equipment by level.

Keywords: logistic support system, military cargo, replenishment of stocks, transportation, manufacturability of delivery, transport network. 